International Journal of Korean Humanities and Social Sciences

vol. $6 / 2020$

DOI: http://dx.doi.org/10.14746/kr.2020.06.01

\title{
MOTIVATION INFLUENCING DECISION TO LEARN KOREAN LANGUAGE AMONG CHIANG MAI UNIVERSITY STUDENTS
}

\section{SAYAMON SORNSUWANNASRI, Ph.D.}

Department of Eastern Languages, Faculty of Humanities

Chiang Mai University, Thailand

239 Huay Kaew Rd., Suthep Sub-district, Muang District,

Chiang Mai, 50200, Thailand

sayamon.sorn@elearning.cmu.ac.th

ORCID: https://orcid.org/0000-0002-9225-562X

\begin{abstract}
The objectives of this research are to investigate motivations that influence a decision to learn Korean language, and post-graduation expectations of 102 students studying Korean in Chiang Mai University. A questionnaire was conducted on the students' motivation behind their decision to learn the Korean language and their expectations for Korean language learning after graduation. It was found that the type of motivation that has the highest influence over their Korean language learning is selfmotivation, and they are also motivated by curriculum and institutes, the 'Korean Wave' and the society, defined as social motivation, respectively. Their highest post-graduation expectation for Korean language learning is the ability to converse fluently with Korean people, while the ability to understand
\end{abstract}


Korean songs/dramas/variety programs, the ability to understand Korean society and culture, the ability to get a job using the Korean language, the opportunity to study in South Korea and the opportunity to have new friends are the next highest expectations successively.

Keywords: motivation; Korean language learning; Chiang Mai University students.

\section{치앙마이 대학교 학생들의 한국어 학습 결정에 영향을 미치는 동기}

초록: 이 연구의 목적은 치앙마이 대학교에서 한국어 학습자 102 명의 한국어 학습 결정에 영향을 미치는 동기를 조사하는 것이고, 이에 따라 한국어를 배우기로 결정한 동기 및 졸업 후 지속적인 한국어 학습에 대한 기대치에 관한 설문을 실시하였다. 설문 조사를 통해 얻은 결과를 보면, 한국어 학습에 영향을 미치는 가장 큰 동기는 자기 동기 부여라는 것이며, 그 다음으로 커리큘럼과 교육 기관, '한류'와 사회적 동기를 통해 부여 받았다는 것이다. 교육 기관 내에서의 한국어 학습을 마치고 졸업 후 학습자들이 가장 기대하는 것은 한국인과 유창하게 대화 할 수 있는 능력을 갖추는 것이다. 그 다음으로는 한국 노래 / 드라마 / 예능프로그램을 이해할 수 있는 능력, 한국 사회와 문화를 이해할 수 있는 능력, 한국어를 사용하여 취업의 기회를 갖는 것, 한국에서 공부할 수 있는 기회 및 한국인 친구를 사귈 수 있는 기회에 대한 기대치가 있다는 것을 알게 되었다.

핵심어: 동기; 한국어 학습; 치앙마이 대학교 학생.

\section{แรงจูงใจในการเลือกเรียนภาษาเกาหลีของนักศึกษามหาวิทยาลัยเชียงใหม่}

บทคัดย่อ: งานวิจัยนี้มีวัตถุประสงค์เพื่อศึกษาเกี่ยวกับแรงจูงใจในการเลือกเรียนภาษา เกาหลีและความคาดหวังหลังเรียนจบของของนักศึกษามหาวิทยาลัยเชียงใหม่ จำนวน 102 คนที่กำลังเรียนภาษาเกาหลี โดยใช้แบบสอบถามเป็นเครื่องมือในการสำร วจแรงจูงใจในการเลือกเรียนภาษาเกาหลีและสำรวจความคาดหวังของผู้เรียนภาษาเกา หลีหลังเรียนจบจากสถาบันการศึกษาของตน ผลการวิจัยพบว่า แรงจูงใจในการเลือกเรี ยนภาษาเกาหลีของกลุ่มตัวอย่างอันดับแรกคือแรงจูงใจจากตนเอง รองลงมาคือแรงจูงใ จจากหลักสูตรและสถาบันการศึกษา รองลงมาคือแรงจูงใจจากกระแสนิยม และอันดับสุ ดท้ายคือ แรงจูงใจจากสังคมแวดล้อม ส่วนความคาดหวังหลังเรียนจบจากสถาบันการศึ กษาของกลุ่มตัวอย่างอันดับแรกคือ สามารถสนทนาภาษาเกาหลีกับคนเกาหลืได้อย่าง คล่องแคล่ว รองลงมาคือสามารถเข้าใจเพลง/ ซีรีส์/ รายการวาไรตี้เกาหลีได้เป็นอย่างดี เข้าใจสังคมและวัฒนธรรมเกาหลีเป็นอย่างดี สามารถนำความรู้ภาษาเกาหลีไปใช้ประ 
กอบอาชีพได้ มีโอกาสได้ไปศึกษาต่อ ณ ประเทศเกาหลีใต้ และได้รู้จักเพื่อนใหม่มากขึ้ น ตามลำดับ.

คำสำคัญ: แรงจูงใจ; การเรียนภาษาเกาหลี; นักศึกษามหาวิทยาลัยเชียงใหม่.

\title{
MOTYWACJA I JEJ WPLYW NA DECYZJĘ O PODJĘCIU NAUKI JĘZYKA KOREAŃSKIEGO PRZEZ STUDENTÓW UNIWERSYTETU CHIANG MAI
}

\begin{abstract}
Abstrakt: Celem niniejszego artykułu jest analiza motywacji wpływającej na decyzję o podjęciu nauki języka koreańskiego oraz na oczekiwania po zakończeniu studiów u 102 studentów Uniwersytetu Chiang Mai. Wśród studentów-respondentów przeprowadzono ankietę by ustalić motywację leżącą u podłoża takiej decyzji oraz wpływającą na ich oczekiwania związane z nauką języka po ukończeniu edukacji. Wyniki wskazują, że do podjęcia tej decyzji skłaniała studentów w największym stopniu motywacja własna; studenci byli także zmotywowani programem studiów i instytucjami edukacyjnymi, koreańskg fala (Korean Wave) oraz społeczeństwem ujmowanym przez pryzmat motywacji społecznej. Umiejętność płynnej komunikacji z Koreańczykami po ukończeniu studiów stanowiła najbardziej pożądane i oczekiwane osiągnięcie. Wśród kolejnych pożądanych umiejętności wskazywano kolejno zrozumienie koreańskich programów telewizyjnych i muzyki, zrozumienie społeczeństwa i kultury koreańskiej, szansę na podjęcie pracy $\mathrm{z}$ wykorzystaniem tego języka, możliwość studiowania $\mathrm{w}$ Korei Południowej jak i szansę na zawiązanie nowych przyjaźni.
\end{abstract}

Słowa klucze: motywacja; nauka języka koreańskiego; studenci Uniwersytetu Chiang Mai.

\section{Introduction}

Thailand and South Korea have a long history in relationship. They have become closer and grown more mutual cooperations. Thai Government has also welcomed more and more Korean businesses and investment in such areas as restaurants and technology-related industrial enterprises. Consequently, the Korean language as an essential tool in bilateral communication in all aspects, ranging from tourism, medical cooperation, commerce, cultural exchanges, has 
become increasingly popular and significant among Thais. Also, a number of Thai students interested in learning Korean language and culture has been growing larger within a few decades. While the aforementioned factors might contribute to an increase in the number of students learning Korean, I believe that there is still a need for further studies on students' motivation to learn Korean.

First of all, I have to mention that this research derived a partial data of my another, recently published paper of the same research area, titled "Motivation Factors Affecting Korean Language Learning in Secondary Schools and Universities in the Upper Northern Region of Thailand" (see Sornsuwannasri 2020). Inspite of the similarity of the title of this research, there is a difference in a scope of target group, which leads to different results. The earlier research included broader participants group, which were students from five secondary schools, and three universities in the upper northern region of Thailand, whereas this paper will concentrate on examining only students of Chiang Mai University, Thailand. There were statistics analysis, including rating scales of each types of motivation and expectation of students after graduation, and also the significant correlation between personal data (age, gender, level of education, etc.) and the types of motivation affecting Korean language learning. Whereas this research will focus on analyzing rating scales of each types of motivation and expectation of students, excluding a correlation analysis between personal data and the types of motivation.

The number of Chiang Mai University students registered for Korean classes are also increasing significantly every year. The primary research in my classrooms presented various reasons that made the students interested in Korean language. Therefore, it is imperative to study motivation and factors influencing Korean language learning decision among Chiang Mai University students as Chiang Mai, a province with social and cultural diversity, is experiencing economic expansion and a rising influx of Koreans, hence emphasizing the importance of Korean language capability. Therefore, I believe that this research, focusing on this data group, is instrumental in providing comprehensive information about the initial motivation of the students and, subsequently, in developing and improving Korean language teachings in the university so as to best responds to the needs of learners as well. Therfore, the objectives of this research are 1) to investigate motivation influencing Chiang Mai University students' decision to 
learn the Korean language; and 2) to examine the students' expectations for Korean language learning after graduation.

\section{Important Notions and Researches ${ }^{1}$}

\subsection{Theories of Needs, Motivation and Expectations}

Among renowned scholars working on needs as the basis of motivation, were Maslow (1954) and Alderfer (1969). Both of them focused on needs, yet classified them in different way. Maslow gave five levels of needs, depending on their relevance to a person: physiological needs, safety needs, social needs, esteem needs and self-actualization need. Alderfer modified this concept and classified needs into 3 types: existence needs, relatedness needs and growth needs. Below there is a graph presenting a corelation between these two classicifations:

Figure 1. The correlation between 'Hierarchy of Needs' and 'ERG Theory' (cf. Maslow 1954; Alderfer 1969)

Hierarchy of Needs

ERG Theory

Physiological Needs: air, food, clothing, shelter, medicine, etc.

Safety Needs: personal/financial safety and security, etc.

Existence Needs

Social Needs: acceptance, recognition from others, etc.

Esteem Needs: admiration and respect from others, self-esteem, etc.

Self-Actualization Needs: achievement, exploiting talents and capabilities, etc.

${ }^{1}$ Some of the theories and researches; e.g. a comparison of Maslow's (1954) Hierarchy of Needs and Alderfer's (1969) ERG Theory, motivation categorized by Spaulding (1992), Gardner (1996) and Moore (2009), SL learning motivation categorized by Gardner and Lambert (1972), and Vroom's (1964) Expectancy Theory were previously presented in Sornsuwannasri (2020: 155-159). Due to the same field of research, these theories and researches are crucial to be mentioned here. A permission to refer those theories and researches in the paper was officially granted. 
The three similarities between Alderfer's ERG Theory and Maslow's Hierarchy of Need Theory involve the fulfilled needs, the level of needs, and the unfulfilled needs. As the correlation presented in the graph shows, the level of need fulfillment is crucial in motivation researches. If the need is not fulfilled, then an individual (namely a student) has a strong desire to achieve the goal and makes efforts. If the level of lower needs is satisfying, then an increase in higher needs can be observed. There are also needs that were unfulfilled (or the high needs were barely fulfilled) and in such situation lower-level gains importance.

Nature of motivation led some psychologists to the concept that there are 2 main types: extrinsic (factors are from outside and the result can be of two type: positive and negative) and intrinsic (one's personal, inner desires) (cf. Spaulding 1992; Gardner 1996; Moore 2009).

Figure 2. Types of motivation categorized by psychologists (cf. Spaulding 1992; Gardner 1996; Moore 2009)

\begin{tabular}{|l|l|}
\hline Extrinsic motivation \\
\cline { 2 - 2 } - Compliments & Intrinsic motivation \\
- Praises & - Interests \\
- Honors & - Attitudes \\
- Etc. & - Gratifications \\
& - Etc. \\
\hline
\end{tabular}

Despite the two types of motivation are useful factors influencing a person to accomplish the target, it is found that the intrinsic motivation is more powerful and effective than the extrinsic motivation in a foreign language learning circumstance. Rubenfeld et al (2007) investigated the two groups of ESL students having different goals of language learning in foreign culture. It was found that learning the language while emerging to the foreign culture is best facilitated both students' motives and goals in harmony. On the other hand, Vansteenkiste et al (2004) had experiments on high school and college students and found that intrinsic goals influenced the improvement of students' learning, performance, and persistence. In addition, Sheldon et al (2004) found that self-determined motives and intrinsic goal contents make significant independent contributions to psychological well-being. Therefore, Geddes (2016: 705) states that "intrinsic motivation among the second language learners should be strongly encouraged". 
Gardner and Lambert (1972) focused on the basis of the desire of the user, explaining that two possible forms of motivation relay on perceiving a learning as a tool for future and possible communication (integrative motivation) or as an accomplishing task tool (instrumental).

Figure 3. Motivation in learning the second language (cf. Garnder and Lambert 1972)

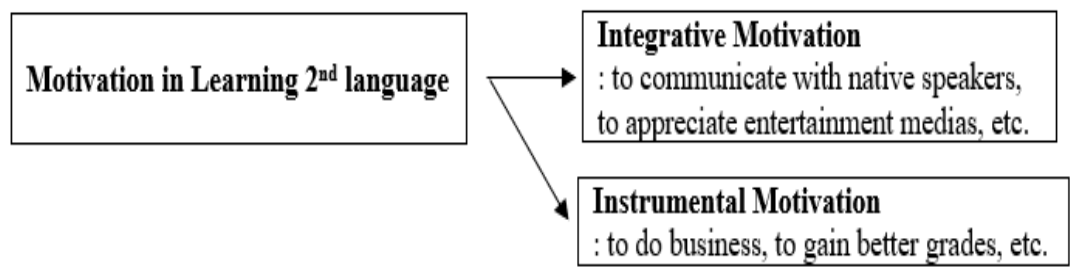

Dörnyei (1994) presented three relatively distinct levels; language level, learner level, and learning situation level; that relate to second language learning motivation. The language level refers to second language circumstance, such as culture or the community, which relates to learner's attitude toward the second language. It also relates to benefits gained from the learner's second language. The learner level refers to individual characteristics of the learner, such as confedence or self-efficacy of using the second language, which bring to the learning process. The learning situation level refers to various aspects of language learning within a classroom setting.

Figure 4. Framework of 2nd language motivation (cf. Dörnyei 1994)

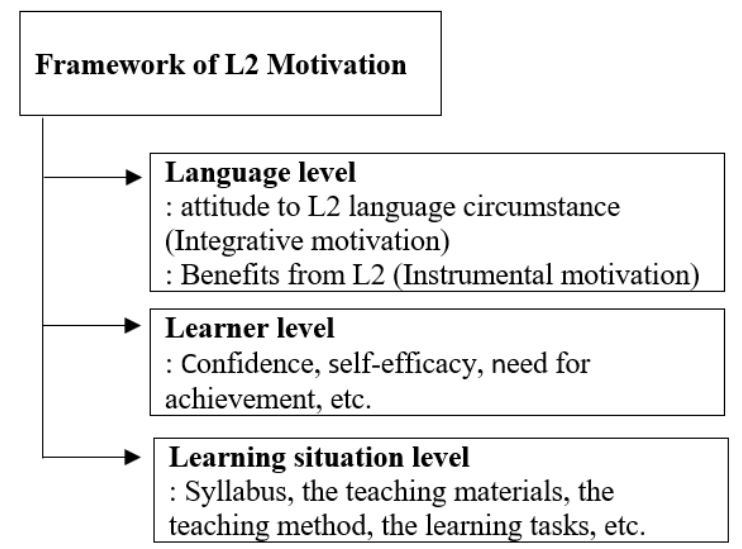


Therefore, motivation can be considered as a vital factor affecting learning because it arouses learners' desire to participate in the learning process, resulting in effective learning and, subsequently, effective application of the knowledge learned in their daily life.

A notion of Expectancy Theory, presenting a corelation between amount of effort if the possible outcome is fulfilling someone's needs had been introduced by Vroom in 1964. This study highlights also intensity of effort and the expectations of the results. In addition, Chen and Fang (2008) has proved the theory by investigating emplyees' performance in Taiwan. The result reveals that their work motivation and behaviors are based on the expecting outcomes.

\subsection{Researches concerning motivation in Korean language learning}

Motivation for learning Korean had recently been widely researched, and become one of the topics discussed in the field of language acquisition, just to mention only a few examples. One of the scholars, who studied the correlation between motivation and Korean Language learning was Root (1999). He implied Dörnyei's model of motivation to the ten week-observation in the USA and realized that there is a relation between teaching style and strategy and motivation.

The correlation between an individual family background (heritage), the presumed importance of Korean language and possible future benefits were among the main motivation factors in the research conducted also in the USA by Damron and Forsyth (2012).

Shon and Jeon (손성희, 전나영 2011) studied students' motivation for learning Korean as a second language. The results show that gender, age, students' first language, proficiency and achievement in Korean have significant differences in the learners' each motivation type.

Jeong (2012) analyzed Korean language learners' motivations and needs, and also analyzed differences among students based on grade level, proficiency level, and status as heritage or non-heritage speaker among students in America. The results reveal that the current 
curriculum affects the strengths and weaknesses in satisfying the expectations and desires of students.

Lee and Kim (2017) investigated the degree of ten motivational factors in learning Korean among Taiwanese students. The result showed that the key motivational factors are interest, desire, communication, the personality of teacher, and curriculum, especially, interest is the most important motivational factor.

As for Thailand, on the motivation among Korean and other foreign languages learners studies were conducted by for example Eadkhao (2011), Maharat (2012), Sukbumperng (2014), Chinakun (2015), Song and Pornsima (2016), Skulthongaram et al. (2018), and Sornsuwannasri (2020).

Personal datas were gathered from Japanese language students in Bangkok is presented in a study by Eadkhao (2011), who concluded that a motivation differed under various social and demographical conditions (namely age, educational background, economical income etc.).

Sukbumperng (2014) investigated the Korean language learning strategies and motivation of secondary school students in Nakhon Si Thammarat province. The research reveals that the students use meta-cognitive strategies and social strategies to learn Korean language. They have more integrative motivation than instrumental motivation in Korean language learning. Also, their high learning strategies are relevant to high motivation significantly.

Chinakun (2015), when researching Bangkok residents' motivation to study Korean had found out, that recently also popular trends and social personal relations are among the motivation determiners.

Aforementioned Gardner's theoretical framework and Attitude Motivation Test Battery used by Song and Pornsima (2016) presented that a high degree of both integrative and instrumental motivation among the students at the King Sejong Institute Foundation in Bangkok was found. However, Skulthongaram et. al (2018) presented that in University of the Thai Chamber of Commerce, the instrumental motivation influences the Korean language major students' decision to study Korean language more.

Sornsuwannasri (2020) examined the motivation affecting Korean language learning, the expectation after graduation from institutes, and the correlation of personal data influencing motivation factors among students from five secondary schools and three 
universities students in the Upper Northern Region of Thailand. The questionnaire replied by 400 participants were analyzed to see the scales of the motivation factors affecting Korean language learning and the expectation after graduation. T-test and F-test were analyzed to see the correlation between personal data and motivation factors. The results reveal that the most motivation affecting Korean language learning is self-motivation; the most expectation after graduation from institutes is the ability to understand Korean songs/series/variety programs; gender affects Korean wave motivation to learn Korean language; age affects self-motivation and social motivation to learn Korean language; level of education affects self-motivation, social motivation, and motivation from institutes to learn Korean language. Chiang Mai University students, studying in a Language Institute of the univeristy had been researched for factors relating to learning languages also by Maharat (2012). The study gave a highlight into economical background of the language courses (prices and student's family income and social status), demographical data, the most popular languages, etc. of the groups.

These studies give researchers a valuable insight into learners' needs and motivation for learning foreign languages as well as social expectations regarding foreign language pedagogical directions. It is also apparent that demographic characteristics, such as gender, age, educational background, and financial background, could influence the learners' decision to study foreign languages.

\section{Methodology}

Participants in this study consisted of 102 Chiang Mai University students who take the Korean language as their electives or minor subjects. Convenience Sampling method using a questionnaire publicized via online media was applied in selecting these participants. Data collection was performed during the months of May to June 2019.

In this study, a questionnaire was used in collecting data concerning Chiang Mai University students' motivation behind their decision to learn Korean. The questionnaire covered 1) motivation for the students' decision to learn the Korean language, and 2) students' post-graduation expectations for Korean language learning. Questions 
under the first topic were based on Gardner and Lambert's (1972) theory of motivation and also revised from Chinakun's (1975) questionnaire, in which motivation were categorized into four types, namely self-motivation, social motivation, motivation from popular trends, and motivation from curriculum and academic institutes. Questions under the second topic were designed with reference to the Expectancy Theory of Vroom (1964). ${ }^{2}$

For further details, there are six parts in the questionnaire. The first part consists of questions about participants' demographic profile, namely gender, age, and affiliation (faculty). The second part to the fifth part consists of questions related to four types of motivation in learning Korean language. The sixth part consists of questions concerning their expectations for Korean language learning after graduating from the university. The questions in the second part to the sixth part were Likert Scale questions with a five-point response scale. 5 represents the highest scale of motivation/expectation, and 1 represents the lowest scale of motivation/expectation. The five-point rating scales were interpreted into weighted mean scores (Eadkhao 2011: 35), which represents five rating levels; highest (scores $4.21-5.00$ ), high (scores $3.41-4.20$ ), moderate (scores $2.61-3.40$ ), low (scores $1.81-2.60$ ), and lowest (scores $1.00-1.80$ ).

The reliability of the finished questionnaire was then tested on an experimental group, which consisted of 30 respondents, using SPSS program. The Cronbach's alpha reliability coefficient was found to be 0.833 , a positive value higher than an acceptable reliability level of 0.7 .

Then, data obtained from the questionnaire were analyzed through SPSS (Statistical Package for Social Science) and Microsoft Excel programs. Descriptive statistical techniques: frequency distributions, percentages, mean, standard deviation were applied. The weighted mean scores were also applied in the analysis on students' motivation that influences their decision to learn the Korean language, and analysis on the students' post-graduation expectations for Korean language learning.

\footnotetext{
2 The participants and the questionnaire were in smaller scopes of Sornsuwannasri's (2020) research groups and research instruments. The investigation focusing on a group of Chiang Mai University students in deeper details might lead to further interesting results, therefore, the data is separately analyzed and presented in this paper. A permission to utilise participants' and questionnaires' partial data in Sornsuwannasri (2020) was officially granted.
} 
4. Results

\subsection{Participants' demographic profile}

The participants' demographic profile includes gender, age and academic affiliation. Its frequency and percentage distributions are presented in the following table.

Table 1. Demographic profile of participants

\begin{tabular}{|c|c|c|c|c|c|}
\hline \multicolumn{6}{|c|}{ Demographics Numbers (Percentages) } \\
\hline \multicolumn{2}{|c|}{ Gender } & \multicolumn{2}{|c|}{ Age (years old) } & \multicolumn{2}{|c|}{ Affiliation (Faculty) } \\
\hline Male & $\begin{array}{c}12 \\
(11.76)\end{array}$ & $18-19$ & $\begin{array}{c}11 \\
(10.78)\end{array}$ & Humanities & $\begin{array}{c}54 \\
(52.94)\end{array}$ \\
\hline \multirow[t]{8}{*}{ Female } & $\begin{array}{c}90 \\
(88.24)\end{array}$ & $20-21$ & $\begin{array}{c}55 \\
(53.92)\end{array}$ & Social Sciences & $\begin{array}{c}4 \\
(3.92)\end{array}$ \\
\hline & & $22-23$ & $\begin{array}{c}31 \\
(30.39)\end{array}$ & Science & $\begin{array}{c}26 \\
(25.49)\end{array}$ \\
\hline & & $24-26$ & $\begin{array}{c}5 \\
(4.90)\end{array}$ & Engineering & $\begin{array}{c}1 \\
(0.98)\end{array}$ \\
\hline & & & & Agriculture & $\begin{array}{c}2 \\
(1.96)\end{array}$ \\
\hline & & & & $\begin{array}{l}\text { Veterinary } \\
\text { Medicine }\end{array}$ & $\begin{array}{c}1 \\
(0.98)\end{array}$ \\
\hline & & & & Economics & $\begin{array}{c}4 \\
(3.92) \\
\end{array}$ \\
\hline & & & & $\begin{array}{l}\text { Mass } \\
\text { Communication }\end{array}$ & $\begin{array}{c}4 \\
(3.92)\end{array}$ \\
\hline & & & & $\begin{array}{l}\text { Political } \\
\text { Science }\end{array}$ & $\begin{array}{c}6 \\
(5.88) \\
\end{array}$ \\
\hline Total & $\begin{array}{c}102 \\
(100.00)\end{array}$ & Total & $\begin{array}{c}102 \\
(100.00)\end{array}$ & Total & $\begin{array}{c}102 \\
(100.00)\end{array}$ \\
\hline
\end{tabular}

It is found that:

1) Gender: the majority, 90 participants and equivalent to 88.24 percent, were females, while there were 12 male participants, equivalent to 11.76 percent.

2) Age: age is classified into four age categories: 18 - 19 years, $20-21$ years, $22-23$ years, and $24-26$ years. The majority 
of respondents was in the $20-21$ years category (55 participants; 53.92 percent), and the rest were in the $22-23$ years category ( 31 participants; 30.39 percent), the $18-19$ years category (11 participants; 10.78 percent) and the $24-26$ years category (5 participants; 4.90 percent) successively.

3) Academic affiliation: the respondents were students of nine faculties. The majority of them was from the Faculty of Humanities (54 participants; 52.94 percent), and the rest were from the Faculty of Science (26 participants; 25.49 percent), the Faculty of Political Science (6 participants; 5.88 percent), the Faculties of Social Science, Economics and Mass Communication (4 participants; 3.92 percent each), and the Faculties of Engineering and Veterinary Medicine (1 participant; 0.98 percent each) respectively.

\subsection{Information on motivation for the participants' decision to learn Korean}

This section presents types of motivation that influence the participants' decision to study the Korean language. The study reveals four types, namely self-motivation, social motivation, motivation from popular trends, and motivation from curriculum and academic institutes. The analysis results of each type are presented in a table displaying frequency, percentage, mean, standard deviation, and mean score rating, as displayed below.

Table 2. Self-motivation in Korean language learning

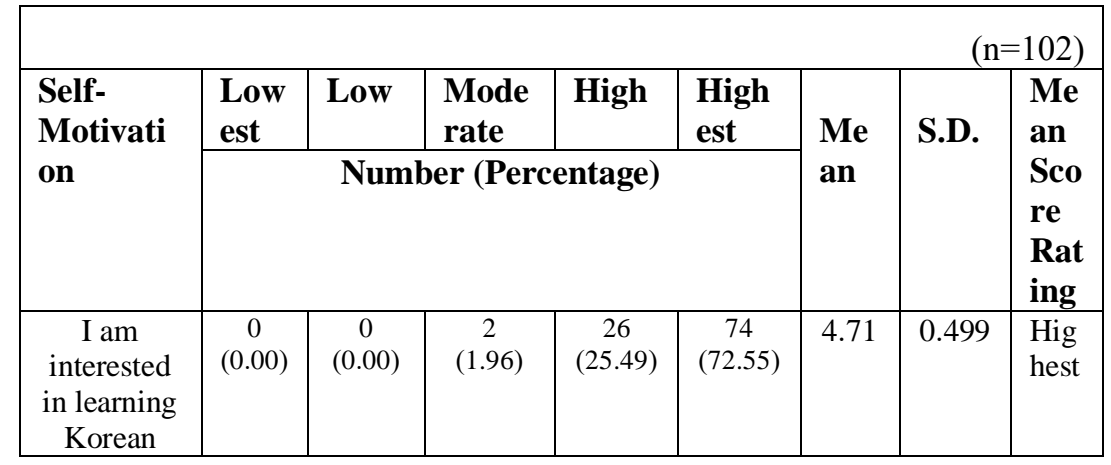




\begin{tabular}{|c|c|c|c|c|c|c|c|c|}
\hline $\begin{array}{c}\text { Studying } \\
\text { Korean } \\
\text { makes me } \\
\text { happy }\end{array}$ & $\begin{array}{c}0 \\
(0.00)\end{array}$ & $\begin{array}{c}0 \\
(0.00)\end{array}$ & $\begin{array}{c}5 \\
(4.90)\end{array}$ & $\begin{array}{c}39 \\
(38.24)\end{array}$ & $\begin{array}{c}58 \\
(56.86)\end{array}$ & 4.52 & 0.593 & $\begin{array}{l}\text { Hig } \\
\text { hest }\end{array}$ \\
\hline $\begin{array}{l}\text { I believe } \\
\text { Korean } \\
\text { capability } \\
\text { will be } \\
\text { beneficial } \\
\text { in the } \\
\text { future }\end{array}$ & $\begin{array}{c}0 \\
(0.00)\end{array}$ & $\begin{array}{c}1 \\
(0.98)\end{array}$ & $\begin{array}{c}11 \\
(10.78)\end{array}$ & $\begin{array}{c}39 \\
(38.24)\end{array}$ & $\begin{array}{c}51 \\
(50)\end{array}$ & 4.37 & 0.716 & $\begin{array}{l}\text { Hig } \\
\text { hest }\end{array}$ \\
\hline $\begin{array}{l}\text { I study } \\
\text { Korean to } \\
\text { enhance } \\
\text { my foreign } \\
\text { language } \\
\text { proficiency }\end{array}$ & $\begin{array}{c}0 \\
(0.00)\end{array}$ & $\begin{array}{c}2 \\
(1.96)\end{array}$ & $\begin{array}{c}3 \\
(2.94)\end{array}$ & $\begin{array}{c}25 \\
(24.51)\end{array}$ & $\begin{array}{c}72 \\
(70.59)\end{array}$ & 4.64 & 0.642 & $\begin{array}{l}\text { Hig } \\
\text { hest }\end{array}$ \\
\hline $\begin{array}{l}\text { I study } \\
\text { Korean to } \\
\text { pursue } \\
\text { higher } \\
\text { education }\end{array}$ & $\begin{array}{c}2 \\
(1.96)\end{array}$ & $\begin{array}{c}7 \\
(6.86)\end{array}$ & $\begin{array}{c}15 \\
(14.71)\end{array}$ & $\begin{array}{c}32 \\
(31.37)\end{array}$ & $\begin{array}{c}46 \\
(45.10)\end{array}$ & 4.11 & 1.024 & $\begin{array}{l}\text { Hig } \\
\mathrm{h}\end{array}$ \\
\hline $\begin{array}{l}\text { I plan to } \\
\text { use Korean } \\
\text { proficiency } \\
\text { in future } \\
\text { careers }\end{array}$ & $\begin{array}{c}2 \\
(1.96)\end{array}$ & $\begin{array}{c}8 \\
(7.84)\end{array}$ & $\begin{array}{c}22 \\
(21.57)\end{array}$ & $\begin{array}{c}25 \\
(24.51)\end{array}$ & $\begin{array}{c}45 \\
(44.12)\end{array}$ & 4.01 & 1.076 & $\begin{array}{l}\text { Hig } \\
\mathrm{h}\end{array}$ \\
\hline \multicolumn{6}{|l|}{ Total } & 4.39 & 0.827 & $\begin{array}{l}\text { Hig } \\
\text { hest }\end{array}$ \\
\hline
\end{tabular}

From Table 2, it is conspicuous that self-motivation as a whole is rated the highest among all types of motivations, with the mean scores of 4.39. Scrutinizing each of the self-motivation related rationales, the students' interest in learning the Korean language ranks the highest of all, having 4.71 mean scores. The rationale with the second highest mean score, 4.64, is that they studied Korean to enhance their foreign language proficiency. Other rationales are: studying Korean made 20 hanc feel happy, rated the highest with 4.52 mean scores; they believed Korean language capability would be beneficial in the future, rated the highest at 4.37; they studied Korean to pursue higher education, rated high at 4.11; and they studied Korean as they planned to use Korean language proficiency in their future careers, rated high with the mean scores of 4.01 . 
Table 3. Social motivation in Korean language learning

\begin{tabular}{|c|c|c|c|c|c|c|c|c|}
\hline \multirow{2}{*}{$\begin{array}{c}\text { Social } \\
\text { Motivatio } \\
\text { n }\end{array}$} & & & & & & \multirow{3}{*}{$\begin{array}{c}\text { Me } \\
\text { an }\end{array}$} & \multicolumn{2}{|c|}{$(n=102)$} \\
\hline & $\begin{array}{c}\text { Lowe } \\
\text { st } \\
\end{array}$ & Low & $\begin{array}{c}\text { Mode } \\
\text { rate }\end{array}$ & High & $\begin{array}{c}\text { High } \\
\text { est }\end{array}$ & & \multirow{2}{*}{$\begin{array}{l}\text { S. } \\
\text { D. }\end{array}$} & $\begin{array}{c}\text { Mea } \\
\mathbf{n}\end{array}$ \\
\hline $\mathbf{n}$ & \multicolumn{5}{|c|}{ Number (Percentage) } & & & $\begin{array}{c}\text { Scor } \\
\text { e } \\
\text { Rati } \\
\text { ng }\end{array}$ \\
\hline $\begin{array}{c}\text { I am } \\
\text { encouraged } \\
\text { / supported } \\
\text { by family to } \\
\text { study } \\
\text { Korean } \\
\end{array}$ & $\begin{array}{c}4 \\
(3.92)\end{array}$ & $\begin{array}{c}9 \\
(8.82)\end{array}$ & $\begin{array}{c}6 \\
(25.49)\end{array}$ & $\begin{array}{c}30 \\
(29.41)\end{array}$ & $\begin{array}{c}33 \\
(32.35)\end{array}$ & 3.77 & $\begin{array}{l}1.1 \\
16\end{array}$ & High \\
\hline $\begin{array}{c}\text { I am } \\
\text { persuaded } \\
\text { by friends } \\
\text { to study } \\
\text { Korean } \\
\end{array}$ & $\begin{array}{c}45 \\
(44.12)\end{array}$ & $\begin{array}{c}20 \\
(19.61)\end{array}$ & $\begin{array}{c}17 \\
(16.67)\end{array}$ & $\begin{array}{c}14 \\
(13.73)\end{array}$ & $\begin{array}{c}6 \\
(5.88)\end{array}$ & 2.18 & $\begin{array}{l}1.2 \\
93\end{array}$ & Low \\
\hline $\begin{array}{c}\text { I study } \\
\text { Korean to } \\
\text { increase a } \\
\text { chance to } \\
\text { meet new } \\
\text { people }\end{array}$ & $\begin{array}{c}3 \\
(2.94)\end{array}$ & $\begin{array}{c}12 \\
(11.76)\end{array}$ & $\begin{array}{c}27 \\
(26.47)\end{array}$ & $\begin{array}{c}38 \\
(37.25)\end{array}$ & $\begin{array}{c}22 \\
(21.57)\end{array}$ & 3.63 & $\begin{array}{l}1.0 \\
43\end{array}$ & High \\
\hline $\begin{array}{l}\text { I study } \\
\text { Korean to } \\
\text { gain } \\
\text { recognition } \\
\& \text { respect } \\
\text { from others }\end{array}$ & $\begin{array}{c}22 \\
(21.57)\end{array}$ & $\begin{array}{c}23 \\
(22.55)\end{array}$ & $\begin{array}{c}37 \\
(36.27)\end{array}$ & $\begin{array}{c}13 \\
(12.75)\end{array}$ & $\begin{array}{c}7 \\
(6.86)\end{array}$ & 2.61 & $\begin{array}{l}1.1 \\
62\end{array}$ & $\begin{array}{l}\text { Mod } \\
\text { erate }\end{array}$ \\
\hline $\begin{array}{l}\text { I know } \\
\text { some } \\
\text { Koreans } \\
\text { and would } \\
\text { like to } \\
\text { communica } \\
\text { te well with } \\
\text { them } \\
\end{array}$ & $\begin{array}{c}10 \\
(9.80)\end{array}$ & $\begin{array}{c}8 \\
(7.84)\end{array}$ & $\begin{array}{c}11 \\
(10.78)\end{array}$ & $\begin{array}{c}13 \\
(12.75)\end{array}$ & $\begin{array}{c}60 \\
(58.82)\end{array}$ & 4.03 & $\begin{array}{l}1.3 \\
82\end{array}$ & High \\
\hline & & Tota & & & & 3.24 & $\begin{array}{l}1.4 \\
00 \\
\end{array}$ & $\begin{array}{l}\text { Mod } \\
\text { erate }\end{array}$ \\
\hline
\end{tabular}

The total mean scores of 3.24, as shown in table 3, demonstrates that social motivation in the students' Korean language learning is at a moderate level. Under the social motivation category, studying Korean in order to be able to communicate well with the Koreans they know is 
rated high at 4.03. Other rationales are: they studied Koreans following family chance and encouragement, rated high at 3.77; they studied Korean so that they have a chance to meet new people, rated high with 3.63 mean scores; they learned Korean so as to gain recognition and respect from others, rated low at 2.61, and; they studied Korean following friends' persuasions, rated low with the mean scores of 2.18.

Table 4. Motivation from the 'Korean Wave' in Korean language learning

\begin{tabular}{|c|c|c|c|c|c|c|c|c|}
\hline & & & & & & & \multicolumn{2}{|c|}{$(n=102)$} \\
\hline \multirow{2}{*}{$\begin{array}{l}\text { Motivati } \\
\text { on from } \\
\text { "Korean } \\
\text { Wave" }\end{array}$} & $\begin{array}{c}\text { Lowe } \\
\text { st }\end{array}$ & Low & $\begin{array}{c}\text { Mode } \\
\text { rate }\end{array}$ & High & $\begin{array}{c}\text { High } \\
\text { est }\end{array}$ & \multirow{2}{*}{$\begin{array}{c}\text { Me } \\
\text { an }\end{array}$} & \multirow{2}{*}{$\begin{array}{l}\text { S. } \\
\text { D. }\end{array}$} & \multirow{2}{*}{$\begin{array}{c}\text { Mea } \\
\text { n } \\
\text { Scor } \\
\text { e } \\
\text { Rati } \\
\text { ng }\end{array}$} \\
\hline & \multicolumn{5}{|c|}{ Number (Percentage) } & & & \\
\hline $\begin{array}{l}\text { I choose } \\
\text { to study } \\
\text { Korean } \\
\text { because it } \\
\text { is in trend }\end{array}$ & $\begin{array}{c}11 \\
(10.78)\end{array}$ & $\begin{array}{c}15 \\
(14.71)\end{array}$ & $\begin{array}{c}36 \\
(35.29)\end{array}$ & $\begin{array}{c}25 \\
(24.51)\end{array}$ & $\begin{array}{c}15 \\
(14.71)\end{array}$ & 3.18 & $\begin{array}{l}1.1 \\
81\end{array}$ & $\begin{array}{l}\text { Mod } \\
\text { erate }\end{array}$ \\
\hline $\begin{array}{l}\text { I choose } \\
\text { to study } \\
\text { Korean } \\
\text { because I } \\
\text { like } \\
\text { Korean } \\
\text { singers/ } \\
\text { actors }\end{array}$ & $\begin{array}{c}3 \\
(2.94)\end{array}$ & $\begin{array}{c}2 \\
(1.96)\end{array}$ & $\begin{array}{c}9 \\
(8.82)\end{array}$ & $\begin{array}{c}16 \\
(15.69)\end{array}$ & $\begin{array}{c}72 \\
(70.59)\end{array}$ & 4.49 & $\begin{array}{l}0.9 \\
52\end{array}$ & $\begin{array}{c}\text { High } \\
\text { est }\end{array}$ \\
\hline $\begin{array}{l}\text { I choose } \\
\text { to study } \\
\text { Korean } \\
\text { because I } \\
\text { like } \\
\text { Korean } \\
\text { songs/ } \\
\text { series/ } \\
\text { variety } \\
\text { programs }\end{array}$ & $\begin{array}{c}0 \\
(0.00)\end{array}$ & $\begin{array}{c}4 \\
(3.92)\end{array}$ & $\begin{array}{c}7 \\
(6.86)\end{array}$ & $\begin{array}{c}23 \\
(22.55)\end{array}$ & $\begin{array}{c}68 \\
(66.67)\end{array}$ & 4.52 & $\begin{array}{l}0.7 \\
93\end{array}$ & $\begin{array}{c}\text { High } \\
\text { est }\end{array}$ \\
\hline
\end{tabular}


IJKHSS 6/2020

\begin{tabular}{|c|c|c|c|c|c|c|c|c|}
\hline $\begin{array}{c}\text { I choose } \\
\text { to study } \\
\begin{array}{c}\text { Korean to } \\
\text { learn } \\
\text { about its } \\
\text { society } \\
\text { and } \\
\text { culture }\end{array}\end{array}$ & $\begin{array}{c}1 \\
(0.98)\end{array}$ & $(3.92)$ & $(13.73)$ & $(34.31)$ & $(47.06)$ & 4.23 & 0.9 & $\begin{array}{c}\text { High } \\
\text { est }\end{array}$ \\
\hline \multicolumn{1}{|c|}{ Total } & & & $\mathbf{4 . 1 0}$ & $\mathbf{1 . 1}$ & High \\
\hline
\end{tabular}

Information in Table 4 shows that, at the total mean scores of 4.1 , the students' motivation from the current popular trends favoring things Korean, known as the "Korean Wave", is high. The highest-ranked rationale under this category, scored 4.49 , is that they chose to learn Korean because they liked Korean songs/series variety shows. Other rationales include: studying the Korean language because they wanted to learn about Korean society and culture, rated the highest at 4.23, and; they chose to study Korean because it was in trend to do so, rated moderate with 3.18 mean scores.

Table 5. Motivation from curriculum and academic institutes in Korean language learning

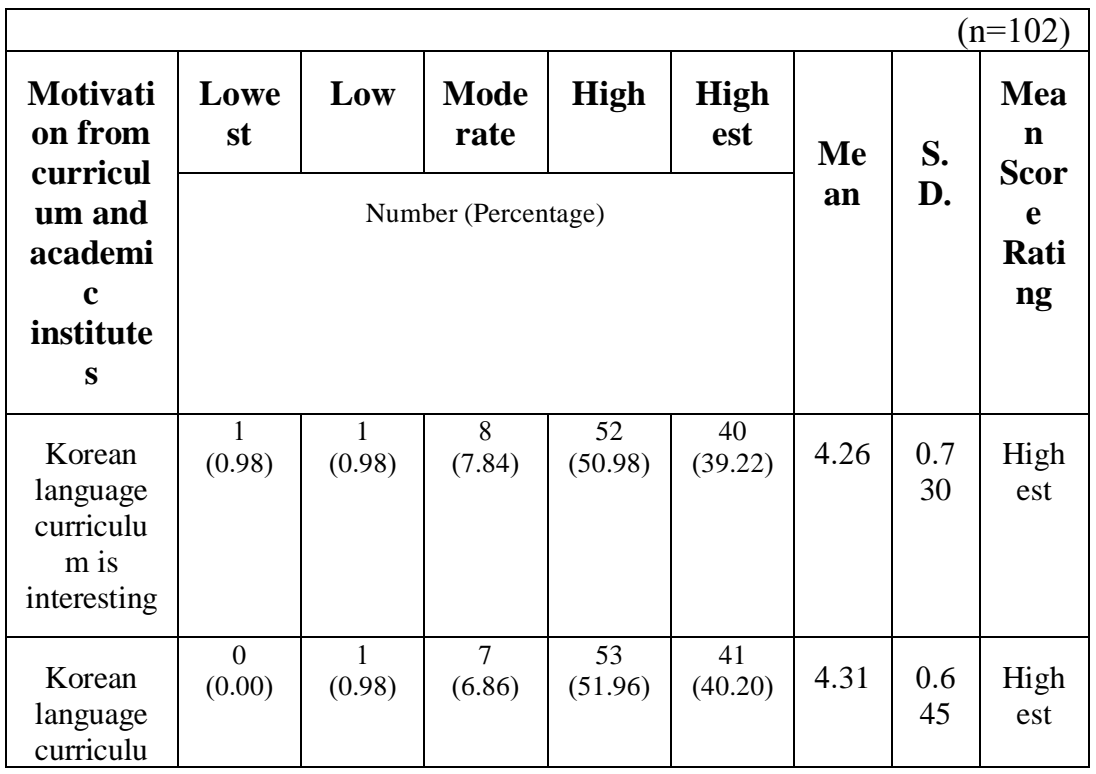




\begin{tabular}{|c|c|c|c|c|c|c|c|c|}
\hline $\begin{array}{l}\quad \mathrm{m} \\
\text { responds } \\
\text { to what I } \\
\text { want to } \\
\text { learn }\end{array}$ & & & & & & & & \\
\hline $\begin{array}{c}\text { Korean } \\
\text { language } \\
\text { curriculu } \\
\text { m helps } \\
\text { improve } \\
\text { language } \\
\text { proficienc } \\
\text { y }\end{array}$ & $\begin{array}{c}1 \\
(0.98)\end{array}$ & $\begin{array}{c}0 \\
(0.00)\end{array}$ & $\begin{array}{c}6 \\
(5.88)\end{array}$ & $\begin{array}{c}41 \\
(40.20)\end{array}$ & $\begin{array}{c}54 \\
(52.94)\end{array}$ & 4.44 & $\begin{array}{c}0.6 \\
98\end{array}$ & $\begin{array}{c}\text { High } \\
\text { est }\end{array}$ \\
\hline $\begin{array}{l}\text { Modern \& } \\
\text { up-to-date } \\
\text { instruction } \\
\text { al media } \\
\text { is used in } \\
\text { Korean } \\
\text { teaching }\end{array}$ & $\begin{array}{c}0 \\
(0.00)\end{array}$ & $\begin{array}{c}1 \\
(0.98)\end{array}$ & $\begin{array}{c}17 \\
(16.67)\end{array}$ & $\begin{array}{c}46 \\
(45.10)\end{array}$ & $\begin{array}{c}38 \\
(37.25)\end{array}$ & 4.19 & $\begin{array}{c}0.7 \\
41\end{array}$ & High \\
\hline $\begin{array}{c}\text { Korean } \\
\text { teachers' } \\
\text { techniques } \\
\text { make } \\
\text { learning } \\
\text { Korean } \\
\text { enjoyable } \\
\text { and easy } \\
\text { to } \\
\text { understan } \\
\text { d }\end{array}$ & $\begin{array}{c}0 \\
(0.00)\end{array}$ & $\begin{array}{c}1 \\
(0.98)\end{array}$ & $\begin{array}{c}5 \\
(4.90)\end{array}$ & $\begin{array}{c}45 \\
(44.12)\end{array}$ & $\begin{array}{c}51 \\
(50.00)\end{array}$ & 4.43 & $\begin{array}{l}0.6 \\
37\end{array}$ & $\begin{array}{c}\text { High } \\
\text { est }\end{array}$ \\
\hline $\begin{array}{c}\text { Korean } \\
\text { teachers } \\
\text { always } \\
\text { understan } \\
\text { d and pay } \\
\text { high } \\
\text { attention } \\
\text { to students }\end{array}$ & $\begin{array}{c}0 \\
(0.00)\end{array}$ & $\begin{array}{c}0 \\
(0.00)\end{array}$ & $\begin{array}{c}5 \\
(4.90)\end{array}$ & $\begin{array}{c}37 \\
(36.27)\end{array}$ & $\begin{array}{c}60 \\
(58.82)\end{array}$ & 4.54 & $\begin{array}{l}0.5 \\
92\end{array}$ & $\begin{array}{c}\text { High } \\
\text { est }\end{array}$ \\
\hline $\begin{array}{c}\text { Korean is } \\
\text { taught by } \\
\text { native- }\end{array}$ & $\begin{array}{c}0 \\
(0.00)\end{array}$ & $\begin{array}{c}0 \\
(0.00)\end{array}$ & $\begin{array}{c}1 \\
(0.98)\end{array}$ & $\begin{array}{c}4 \\
(3.92)\end{array}$ & $\begin{array}{c}97 \\
(95.10)\end{array}$ & 4.94 & $\begin{array}{l}0.2 \\
75\end{array}$ & $\begin{array}{c}\text { High } \\
\text { est }\end{array}$ \\
\hline
\end{tabular}




\begin{tabular}{|c|c|c|c|c|c|c|c|c|}
\hline $\begin{array}{l}\text { speaking } \\
\text { teachers }\end{array}$ & & & & & & & & \\
\hline $\begin{array}{l}\text { Classroom } \\
\text { environme } \\
\text { nt is good } \\
\text { and } \\
\text { conducive } \\
\text { to learning }\end{array}$ & $\begin{array}{c}0 \\
(0.00)\end{array}$ & $\begin{array}{c}1 \\
(0.98)\end{array}$ & $\begin{array}{c}13 \\
(12.75)\end{array}$ & $\begin{array}{c}48 \\
(47.06)\end{array}$ & $\begin{array}{c}40 \\
(39.22)\end{array}$ & 4.25 & $\begin{array}{c}0.7 \\
10\end{array}$ & $\begin{array}{c}\text { High } \\
\text { est }\end{array}$ \\
\hline $\begin{array}{l}\text { There are } \\
\text { many } \\
\text { extra- } \\
\text { curricular } \\
\text { activities } \\
\text { in addition } \\
\text { to } \\
\text { classroom } \\
\text { learning }\end{array}$ & $\begin{array}{c}3 \\
(2.94)\end{array}$ & $\begin{array}{c}4 \\
(3.92)\end{array}$ & $\begin{array}{c}37 \\
(36.27)\end{array}$ & $\begin{array}{c}32 \\
(31.37)\end{array}$ & $\begin{array}{c}26 \\
(25.49)\end{array}$ & 3.73 & $\begin{array}{l}0.9 \\
87\end{array}$ & High \\
\hline $\begin{array}{l}\text { A chance } \\
\text { to pursue } \\
\text { Korean } \\
\text { language } \\
\text { study in } \\
\text { South } \\
\text { Korea is } \\
\text { offered }\end{array}$ & $\begin{array}{c}7 \\
(6.86)\end{array}$ & $\begin{array}{c}7 \\
(6.86)\end{array}$ & $\begin{array}{c}35 \\
(34.31)\end{array}$ & $\begin{array}{c}29 \\
(28.43)\end{array}$ & $\begin{array}{c}24 \\
(23.53)\end{array}$ & 3.55 & $\begin{array}{l}1.1 \\
31\end{array}$ & High \\
\hline \multicolumn{6}{|c|}{ Total } & 4.26 & $\begin{array}{l}0.8 \\
32\end{array}$ & $\begin{array}{c}\text { High } \\
\text { est }\end{array}$ \\
\hline
\end{tabular}

According to Table 5, motivation from curriculum and academic institutes behind the participants' decision to learn Korean is found to be at the highest level, with the total mean scores of 4.26. The highestrated rationale is that Korean classes were taught by native-speaking teachers, scored at 4.94. The second highest rationale with the mean scores of 4.54 is Korean teachers always understood and paid high attention to students. Other rationales behind the participants' decision to learn Korean are: Korean language curriculum helped improve their language proficiency, rated the highest at 4.44; Korean teachers applied teaching techniques that made the learning enjoyable and easy to understand, rated the highest at 4.43; the content of Korean language curriculum responded to what they wanted to learn, rated the highest at 4.31; Korean language curriculum was interesting, rated the highest at 
4.26; the classroom environment was good and conducive to learning, rated the highest at 4.25; modern and up-to-date instructional media was used in Korean language teaching, rated high at 4.19; there were many extra-curricular activities in addition to classroom learning, rated high at 3.73, and; a chance to pursue Korean language study in South Korea was offered at Korean classes, rated high with the mean scores of 3.55.

Table 6. Summary of motivation for Korean language learning

\begin{tabular}{|c|c|c|c|c|c|c|c|c|}
\hline $\begin{array}{c}\text { Motivati } \\
\text { on from }\end{array}$ & $\begin{array}{c}\text { Lo } \\
\text { wes } \\
\mathbf{t}\end{array}$ & $\begin{array}{c}\text { Lo } \\
\mathbf{w}\end{array}$ & $\begin{array}{c}\text { Mod } \\
\text { erate }\end{array}$ & $\begin{array}{c}\text { Hig } \\
\mathbf{h}\end{array}$ & $\begin{array}{c}\text { High } \\
\text { est }\end{array}$ & $\begin{array}{c}\text { Mea } \\
\mathbf{n}\end{array}$ & S.D. & $\begin{array}{c}\text { Mean } \\
\text { Score } \\
\text { Ratin } \\
\mathbf{g}\end{array}$ \\
\hline Self & - & - & - & - & $\checkmark$ & 4.39 & 0.827 & $\begin{array}{c}\text { Highes } \\
\text { t }\end{array}$ \\
\hline $\begin{array}{c}\text { Society } \\
\text { Korean } \\
\text { Wave }\end{array}$ & - & - & $\checkmark$ & - & - & 3.24 & 1.400 & $\begin{array}{c}\text { Moder } \\
\text { ate }\end{array}$ \\
\hline $\begin{array}{c}\text { Curriculu } \\
\text { m and } \\
\text { academic } \\
\text { institutes }\end{array}$ & - & - & - & - & $\checkmark$ & 4.26 & 0.832 & $\begin{array}{c}\text { Highes } \\
\text { High }\end{array}$ \\
\hline
\end{tabular}

Table 6 illustrates and summarizes the significance of each type of motivation that influences the participants' decision to learn the Korean language. Self-motivation is observed to have the highest impact on the students' motivation, with the mean score of 4.39. Another highestimpact motivation is the one from curriculum and academic institutes, having 4.26 mean scores. Motivation from popular trends is rated high at 4.1, while the lowest ranking motivation in this group is social motivation, rated moderate with the mean scores of 3.24. 


\subsection{Students' post-graduation expectations for Korean language learning}

This section elaborates on the students' expectations for their Korean language study after graduating from the university. Results of the analysis are presented in the following table, which include frequency, percentage, mean, standard deviation, and mean score level.

Table 7. Students' post-graduation expectations for Korean language learning

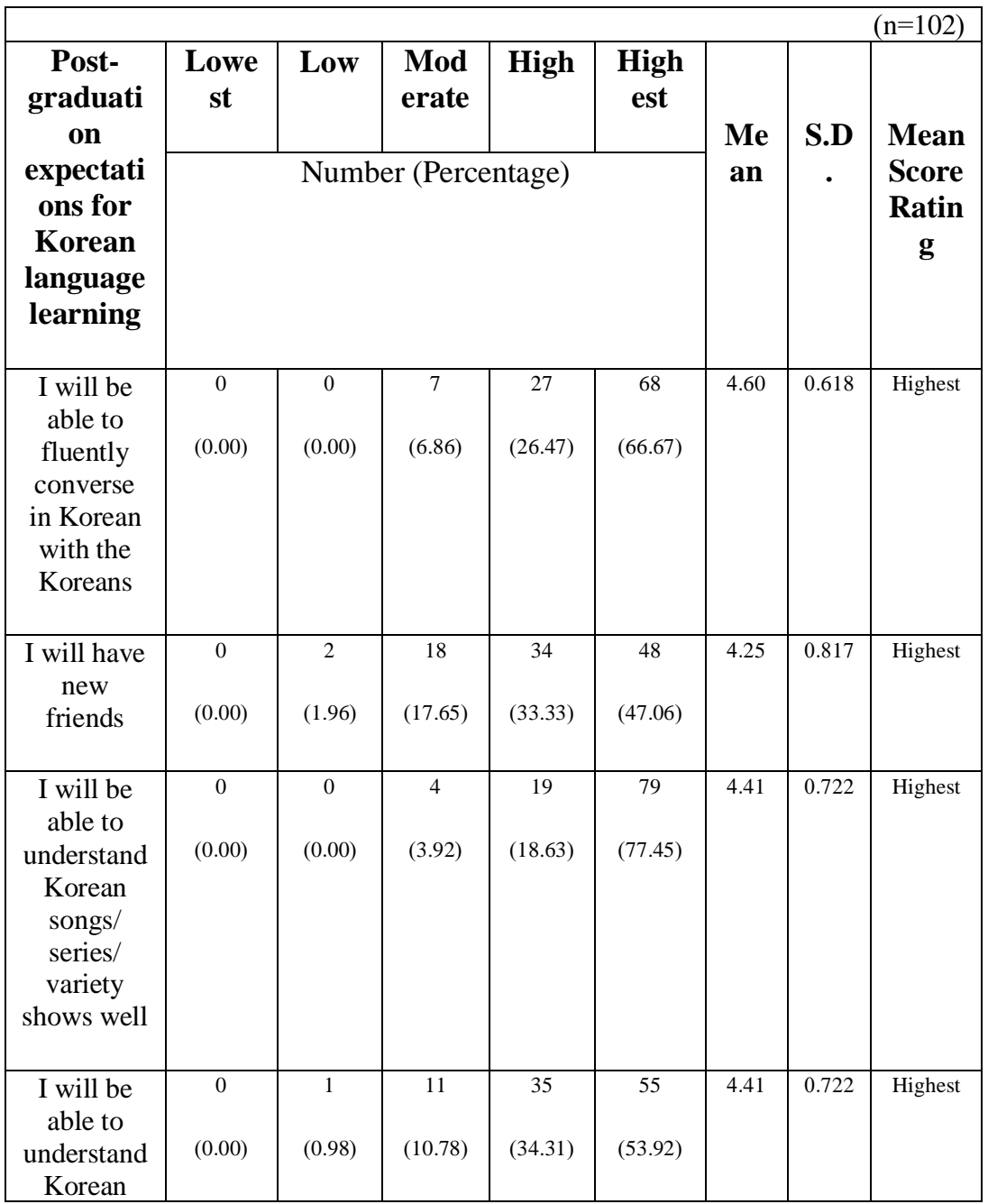




\begin{tabular}{|c|c|c|c|c|c|c|c|c|}
\hline $\begin{array}{c}\text { society \& } \\
\text { culture } \\
\text { well }\end{array}$ & & & & & & & & \\
\hline $\begin{array}{l}\text { I will have } \\
\text { a chance to } \\
\text { further my } \\
\text { study in } \\
\text { South } \\
\text { Korea }\end{array}$ & $\begin{array}{c}0 \\
(0.00)\end{array}$ & $\begin{array}{c}5 \\
(4.90)\end{array}$ & $\begin{array}{c}17 \\
(16.67)\end{array}$ & $\begin{array}{c}23 \\
(22.55)\end{array}$ & $\begin{array}{c}57 \\
(55.88)\end{array}$ & 4.29 & 0.918 & Highest \\
\hline $\begin{array}{l}\text { I will be } \\
\text { able to use } \\
\text { my Korean } \\
\text { language } \\
\text { proficienc } \\
\text { y in my } \\
\text { future } \\
\text { careers }\end{array}$ & $\begin{array}{c}1 \\
(0.98)\end{array}$ & $\begin{array}{c}3 \\
(2.94)\end{array}$ & $\begin{array}{c}10 \\
(9.80)\end{array}$ & $\begin{array}{c}28 \\
(27.45)\end{array}$ & $\begin{array}{c}60 \\
(58.82)\end{array}$ & 4.40 & 0.859 & Highest \\
\hline
\end{tabular}

The overall post-graduation expectations of the students for their Korean language study are found to be at 4.45 mean scores, which can be interpreted as the highest level. The highest-ranking expectation is that they will be able to fluently converse in Korean with the Koreans, rated highest at 4.60. The next highest-ranking expectations are that they will be able to understand Korean songs/ series/ variety shows well and that they will be able to understand Korean society \& culture well, both of which were rated the highest with the mean scores of 4.41. Other expectations include: they will be able to use their Korean language proficiency in future careers, rated the highest at 4.40; they will have a chance to further their study in South Korea, rated the highest at 4.29, and; they will have new friends, rated the highest with the mean scores of 4.25. To sum up, the participants are found to have the highest level of expectations for Korean language learning in every aspect after graduating from the university.

\section{Conclusion}

This study, titled Motivation Influencing Decision to Learn Korean Language Among Chiang Mai University Students, is a survey research 
using a questionnaire as an instrument for data collection. The objectives of this study were to examine motivation behind Chiang Mai University students' decision to learn the Korean language as well as to explore their expectations for Korean language learning after graduating from the university. Convenience Sampling method was implemented through a questionnaire to recruit 102 participants among students enrolling in Korean language courses as their electives or minor subjects. Data were collected during May to July 2019, and descriptive statistics, namely frequency, percentage, mean, and standard deviation, were used to analyze the data. The research results were as follows.

\subsection{Participants' demographic profile}

The participants' demographic characteristics, namely gender, age and affiliation, are explained below.

Gender: the majority, 90 participants and equivalent to 88.24 percent, were females, while there were 12 male participants, equivalent to 11.76 percent.

Age: age is classified into four age categories: $18-19$ years, $20-21$ years, $22-23$ years, and $24-26$ years. The majority of respondents was in the $20-21$ years category (55 participants; 53.92 percent), and the rest were in the $22-23$ years category ( 31 participants; 30.39 percent), the $18-19$ years category (11 participants; 10.78 percent) and the $24-26$ years category (5 participants; 4.90 percent) respectively.

Academic affiliation: the respondents are found to be students of nine faculties. The majority of them were from the Faculty of Humanities (54 participants; 52.94 percent), and the rest were from the Faculty of Science (26 participants; 25.49 percent), the Faculty of Political Science (6 participants; 5.88 percent), the Faculties of Social Science, Economics and Mass Communication (4 participants; 3.92 percent each), and the Faculties of Engineering and Veterinary Medicine (1 participant; 0.98 percent each) consecutively. 


\subsection{Participant's motivation influencing their decision to learn Korean language}

From the study, self-motivation is observed to have the highest impact on the participants' motivation to learn Korean, with the mean scores of 4.39. Another motivation with the highest level of impact is the motivation from curriculum and academic institutes, having 4.26 mean scores. Motivation from popular trends is rated high at 4.1 , while social motivation is rated as having a moderate level, with the mean scores of 3.24 .

Comparing to the results of Sornsuwannasri (2020), both secondary and university students have the highest scales of selfmotivation to learn Korean, which is the same as the results of this research. The interesting difference is the second result of motivation type. Both researches found that the second level of impact is the motivation from curriculum and academic institutes, however this type of motivation was not rated into the highest scales in Sornsuwannasri (2020). This means Chiang Mai University students focus on a curriculum and academic institutes' quality more than the secondary schools and universities students in the upper northern region of Thailand combined.

\subsection{Participants' post-graduation expectations for Korean language learning}

The students' overall post-graduation expectations for their Korean study are observed to be at the highest level, with the total mean scores of 4.45. The highest-ranking expectation is that they will be able to converse in Korean fluently with Korean native speakers, rated highest at 4.60. The participants then expect to be able to understand Korean songs/series/variety shows well and to be able to understand Korean society and culture well, both rated the highest at 4.41 mean scores. Other expectations are: they will be able to use their Korean language proficiency in future careers, rated the highest at 4.40; they will have a chance to further their study in South Korea, rated the highest at 4.29, and; they will have new friends, rated the highest with the mean scores 
of 4.25. Hence, it can be summarized that the participants have the highest expectations for Korean language learning in every aspect after graduation.

\section{Discussion}

\subsection{Discussion on motivations for Korean language learning}

The findings show that self-motivation plays a key role in most participants' decision to study the Korean language, evidenced by the highest scores among all types of motivation. This is in line with many related studies, which indicated that self-motivation is the most influential factor affecting learners' decision to learn any language. The second important motivation, yet also rated the highest in terms of its influence, is the motivation from curriculum and academic institutes. This point might be beneficial to academic institutes in designing a high-quality, motivational curriculum and teaching techniques so as to attract students. The next significant motivation, rated high, is motivation from popular trends. K-pop has undoubtedly been an extremely popular and favorable trend that fosters a greatly positive attitude towards South Korea and the Korean language, hence making it a powerful and indispensable force in motivating a large number of youths and fans to learn Korean. The least significant motivation found through this research is social motivation, which was rated moderate among the participants in terms of its impact on their decision to learn the Korean language.

In conclusion, the study results suggest that the students' decision to study Korean is most influenced by self-motivation, which is intrinsic motivation. The result has reflected a congruence with Vansteenkiste et al (2004), Sheldon et al (2004), and Geddes (2016) which their researches support intrinsic motivation among the second language learners. On the other hand, extrinsic motivation, which in this this research covers motivation from curriculum, popular trends and the society successively, is observed to be less instrumental in their Korean 
learning decision. However, it is worth noting that the more conducive to learning such extrinsic motivation is, as well as the better such extrinsic motivation can develop a positive attitude towards Korean language learning, the higher its influence on the students' decision to study Korean becomes.

\subsection{Discussion on students' post-graduation expectations for Korean language learning}

It can be seen from the study results that the participants' expectations for their Korean language study reach the highest level in every aspect. These aspects are: the ability to communicate fluently in Korean with the Koreans; the ability to understand Korean songs/ series/ variety shows well; the ability to understand Korean society \& culture well; the ability to use Korean language proficiency in their future careers; a chance to further their study in South Korea, and; a chance to have new friends, respectively.

The students' decision to learn Korean indicates their willingness to sacrifice their time, resources and effort in the study; therefore, highest expectations for satisfying outcomes is quite obvious. Contrariwise, these high expectations can be regarded as a driving force behind their motivation to achieve their goals, which corresponds to Growth Needs in Alderfer's (1966) ERG Theory; and Vroom's (1964) notion stating that increased efforts at work arise from expectations for some satisfying outcomes. For Korean teachers, these results about students' expectation should be noted. The creative designs of Korean curriculum, teaching techniques, etc, in order to meet the learners' most satisfaction, also correspond to Dörnyei's (1994) framework of second language motivation. 


\section{Bibliography}

Alderfer, Clayton P. 1966. Differential Importance of Human Needs as a Function of Satisfaction Obtained in the Organization. Unpublished Doctoral Dissertation, Yale University, New Haven, CT.

Chen, Yei-Yi, Fang, WenChang. 2008. The Moderating Effect of Impression Management on the Organizational PoliticsPerformance Relationship. Journal of Business Ethics 79: 263277. Retrieved December 30, 2020, from https://doi.org/10.1007/s10551-007-9379-3.

Chinakun, Mathumon. 2015. แรงจูงใจที่มีอิทธิพลในการตัดสินใจเลือกเรียนภาษาเกาหลี ใน สถาบันสอนภาษาของประชาชน ในกรุงเทพมหานคร Raeng Chungchai Thi Mi Itthiphon Nai Kantatsinchai Luak Rian Phasa Kaoli Nai Sathaban Son Phasa Khong Prachachon Nai Krung Thep Maha Nakhon (Motivation Affecting the Selection of Korean Language Institutions of the People in Bangkok). Bachelor of Business Administration Thesis, Silpakorn University.

Damron, July and Forsyth, Justin. 2012. Korean Language Studies: Motivation and Attrition. Journal of the National Council of Less Commonly Taught Languages 12: 161-188. Retrieved January 30, 2020, from http://www.ncolctl.org/files/koreanlanguage.pdf.

Dörnyei, Zoltán. 1994. Motivation and Motivating in the Foreign Language Classroom. Modern Language Journal 78(3): 273284. Retrieved January 30, 2020, from https://doi.org/10.2307/330107.

Eadkhao, Sukanya. 2011. ปัจจัยที่ส่งผลต่อการตัดสินใจเลือกเรียนภาษาญี่ปุนนี่เรงเรียนสอน ภาษาญี่ปุ่นในกรุงเทพมหานคร Patchai Thi Song Phon To Kantatsinchai Luak Rian Phasa Yipun Thi Rongrian Son Phasa Yipun Nai Krung Thep Maha Nakhon (Factor Affecting the Selection of Japanese Language School in Bangkok). Master of Business Administration Thesis, Rajamangala University of Technology Thanyaburi.

Gardner, Robert C. 1996. Motivation and Second Language Acquisition: Perspectives. Journal of the Canadian Association of Applied Linguistics 18: 19-42. 
Gardner, Robert C., and Lambert, Wallace E. 1972. Attitudes and Motivation in Second Language Learning. Rowley, MA: Newbury House Publishers.

Geddes, Aaron J. 2016. Korean University Students' Attitudes and Motivation towards Studying English. Universal Journal of Educational Research 4(4): 704-715. Retrieved December 3, 2020, from https://doi.org/10.13189/ujer.2016.040407.

Jeong, Hee-Jeong. 2012. Needs Analysis of Korean Language Programs. The Korean Language in America 17: 49-62. Retrieved December 3, 2020, from http://www.jstor.org/stable/42922357.

Lee, Cheng-Wen, Kim, Min-Sun. 2017. The Motivation For Learning Korean Among The Taiwanese. Ecoforum Journal 6(3). Retrieved December 3, 2020, from http://www.ecoforumjournal.ro/index.php/eco/article/view/68 $\underline{5 / 425}$.

Maharat, Jenjira. 2012. พฤติกรรมและความพึงพอใจในการเลือกเรียนภาษาต่างประเทศ ใน สถาบันสอนของนักศึกษาระดับปริญญาตรี มหาวิทยาลัยเชียงใหม่ Phruttikam Lae Khwamphungphochai Nai Kanluak Rian Phasa Tangprathet Nai Sathaban Son Khong Naksuksa Radap Parinya Tri Mahawitthayalai Chiang Mai (Behavior And Satisfaction In Choosing to Study Foreign Languages in Teaching Institutions of Undergraduate Students of Chiang Mai University). Research Exercise in Economics, Chiang Mai University.

Maslow, Abraham 1954. Motivation and Personality. New York: Harper.

Moore, Kenneth D. 2009. Effective Instructional Strategies: From Theory to Practice. United States of America: SAGE Publications, Inc.

Root, Elisabeth. 1999. Motivation and Learning Strategies in a Foreign Language Setting: A Look at a Learner of Korean. Minneapolis: Center for Advanced Research on Language Acquisition, University of Minnesota.

Rubenfeld, Sara, Sinclair, Lisa, Clement, Richard. 2007. Second language learning and acculturation: The role of motivation and goal content congruence. Journal of Language and Social Psychology 10(3): 309-323. Retrieved December 30, 2020, from

https://journals.lib.unb.ca/index.php/CJAL/article/view/19748 
Skulthongaram, Tiptida, Kathavee, Amornrat, and Baithong, Wanvisa. 2018. แรงจูงใจในการเรียนภาษาเกาหลี กรณีศึกษาของนักศึกษาวิชาเอกภาษาเกาหลี มหาวิทยาลัยหอการค้าไทย Raeng Chungchai Nai Kan Rian Phasa Kaoli: Korani Suksa Khong Naksuksa Wicha Ek Phasa Kaoli Mahawitthayalai Hokankha Thai (Motivation in Learning Korean Language: The Case Study of Korean Language Major Students at University of the Thai Chamber of Commerce, Thailand). Conference Papers on the 2nd UTCC Academy Day, June 8, 2018, University of the Thai Chamber of Commerce.

Sheldon, Kennon M., Ryan, Richard M., Deci, Edward L. and Kasser, Tim. 2004. The independent effects of goal contents and motives on well-being: It's both what you pursue and why you pursue it. Personality and Social Psychology Bulletin 30: 475486. Retrieved December 30, 2020, from https://doi.org/10.1177/0146167203261883.

Shon, Sunghee (손성희), Jeon, Nayoung (전나영). 2011. 한국어학습자의학습동기분석 Hangugeo Hagseubja-ui Hagseub Tonggi Bunseok (A Study of Language Learning Motivation of Korean Language Learners). 한국어교육 Hangugeo Gyoyug (Journal of Korean Language Education) 22(3): 133-152. Retrieved December 30, 2020, from https://doi.org/10.18209/iakle.2011.22.3.133.

Song, Suji, Pornsima, Derek. 2016. Motivation for Learning among Thai Students Studying Korean as a Foreign Language in Thailand. Scholar: Human Sciences 8(2): 154-164. Retrieved December 30, 2020, from http://www.assumptionjournal.au.edu/index.php/Scholar/articl e/view/2506.

Sornsuwannasri, Sayamon. 2020. ปัจจัยที่มีผลต่อแรงจูงใจในการเลือกเรียนภาษาเกาหลี ระดับมัธยมศึกษาและระดับมหาวิทยาลัยในเขตภาคเหนือตอนบนของประเทศไทย Patjai Thi Mi Phon To Rang Chungchai Nai Kan Reuak Rian Phasa Kaoli Radap Matthayom Suksa La Radap Mahawitthayalai Nai Khet Pak Nuer Tonbon Khong Prathet Thai (Motivation Factors Affecting Korean Language Learning in Secondary Schools and Universities in the Upper Northern Region of Thailand). Journal of Human Sciences. 21(3): 152-176. Retrieved December 30, 2020, from https://so03.tcithaijo.org/index.php/JHUMANS/article/view/243331.

Spaulding, Cheryl L. 1992. Motivation in the Classroom. The United States: McGraw-Hill. 
Sukbumperng, Anutsara. 2014. กลวิธีการเรียนรู้และแรงจูงใจในการเรียนภาษาเกาหลีของ นักเรียนมัธยมในจังหวัดนครศรีธรรมราช Gonlawithee Kan Rian Roo Rae Rang Chungchai Nai Kan Rian Phasa Kaoli Khong Nak Rian Matthayom Nai Changwat Nakhon Si Thammarat (Korean Language Strategies And Motivation Of Secondary School Students in Nakhon Si Thammarat). Master of Arts Thesis, Chulalongkorn University. Retrieved December 30, 2020, from http://cuir.car.chula.ac.th/handle/123456789/46642.

Vansteenkiste, Maarten, Simons, Joke, Lens, Willy, Sheldon, Kennon M., Deci, Edward L. 2004. Motivating learning, performance, and persistence: The synergistic effects of intrinsic goal contents and autonomy-supportive contexts. Journal of Personality and Social Psychology 87: 246-260. Retrieved December 30, 2020, from https://doi.org/10.1037/00223514.87.2.246.

Vroom, Victor H. 1964. Work and Motivation. New York: John Wiley and Sons. 